\title{
HOLY COW IN INDIA: A POLITICAL DISCOURSE AND SOCIAL MEDIA ANALYSIS FOR RESTORATIVE JUSTICE
}

\author{
Muhammad Akram ${ }^{1}$, Asim Nasar ${ }^{2}$, and Muhammad Rizwan Safdar ${ }^{3}$ \\ ${ }^{1}$ Eastern Mennonite University, ${ }^{2}$ Universiti Teknologi Malaysia, \\ and ${ }^{3}$ University of the Punjab
}

\begin{abstract}
The issue of holy cows in India has gained significant importance on social media and connects with the political dilemma between Hindus and Muslims. This paper discusses political discourse and people's dark shades of emotion on social media to cow vigilante violence in India. It elaborates legislation differences on cow slaughter, historical and political aspects of cow vigilante violence against Muslim and Dalit minorities in India. Drawing from literature, the vigilante groups in India use social media platforms to disseminate content on cow vigilantism and publicize spectacles for political benefits. Social activists who support political leaders play a vital role in spreading the cow vigilante violence content through end-to-end encrypted social media apps to create turbulent situations among vulnerable communities. The situation analysis of cow vigilante violence shows that the Hindu nationalists perpetuate violence against Muslims in retribution of perceived historic harm caused by the Muslim rulers of subcontinent India. This paper has identified restorative justice theories that could guide the transformation of cow vigilante violence situation factors into peaceful coexistence of Hindus and Muslims in India. Further, Galtung's peace model added value to ensure the functionality of peacebuilding, peacemaking, and peacekeeping among Hindus, Muslims, and Dalit minorities in India.
\end{abstract}

Keywords: Cow vigilantism; religious minorities; violence; India

DOI: https//doi.org/10.3176/tr.2021.2.04

Received 10 November 2020, accepted 15 January 2021, printed and available online 10 June 2021

(C) 2021 Authors. This is an Open Access article distributed under the terms and conditions of the Creative Commons Attribution-NonCommercial 4.0 International License (http://creativecommons.org/licenses/by-nc/4.0/). 


\section{Introduction}

In India, cow slaughter and beef consumption are extremely unpredictable, emotional, and politicized issues. The avowed sacredness of the cow in Hindu India is at the center of the debates on cow slaughter and beef consumption (Chigateri 2011). In Hinduism, the cow is a holy animal, symbolizing self-giving, nonviolence, and gentleness, which gives human beings more than it takes away from them. Therefore, especially for food, she should not be killed or harmed (Winston 2015). Cow safety, a powerful instrument in the hands of cow vigilantes for atrocities against Muslims and Dalits, has become a heavily politicized issue. Its origins can be traced to the late nineteenth century, linking the themes of caste-Hindu religious sentiment, communalism, and economic logic. Simultaneously, simple problems about the intriguingly complicated use of cattle are far older (Gundimeda and Ashwin 2018). As per statistics, India has 145.12 million cows, 18 percent more than in 2012 (Business Line 2019). Around 1.3 billion people worship cows as goddesses and "cow urine can sell for more than milk in India" (Gowen 2018, Narayanan 2019, Upadhyay 2016). India was the world's largest beef exporter until 2017, but after Narendra Modi was elected India's prime minister, exports decreased, placing India in second place after Brazil (Marlow, 2019). In the election campaign, Narendra Modi's party, Bhartiya Janata Party (BJP), vowed cow safety, creating difficulties for those who are engaged in cow businesses.

India has seen an increase in violent attacks against minorities committed to defend cattle against slaughter since 2015. In the aftermath of legislation passed in several states to tighten restrictions and bans on cattle-slaughter and the selling or possession of beef, laws banning cattle slaughter have been on the books since independence in many Indian states (Adcock 2018). Defense vigilantes, Hindu nationalists who seek to protect cows through blind acts of violence against those whom they accuse of possibly killing the cow, shatter the nonviolent symbolism of cows. In order to perpetuate stereotypes of Indian Muslims as a harmful, anti-national presence and to justify anti-Muslim violence by Hindu vigilantes, both Hindu nationalists and cow protectionists perceive Muslims as the primary opponents of cow protection.

In scholarly literature, cow vigilante violence in India has been less noticed from the point of legislation difference on cow slaughter in different states. Scholars have covered the significance of cow protection in India and minority rights. However, social media influence to raise the cow vigilante violence has been less explored. Moreover, in scholarly literature, the factors causing cow vigilante violence are rarely discussed. Besides, in published research, a theoretical viewpoint associated with cow vigilante activity remains elusive.

This study discusses political discourse and people's dark shades of emotion on social media to cow vigilante violence in India. It describes the legislation difference and political interests that leads towards conflict among Hindus, Muslims and Dalits minorities in India. This paper addresses questions: a) What is the role of the cow in India subject to history and legislation? b) How have social media platforms 
played their part in cow vigilante violence in India? c) How is the restorative justice approach support reducing cow vigilante violence in India?

The paper structure comprises historical, legislations, political, and social media aspects of cow vigilante violence in India. Exploratory research is used to conduct situation analysis using published sources. The analysis section covers the restorative theories and models to practice for addressing the violence amidst cow vigilantism in India.

\subsection{Indian states'legislations on cow protection}

Article 48 of the Constitution of India justifies the prohibition of cow slaughter as: "the State shall endeavor to organize agriculture and animal husbandry on modern and scientific lines and shall, in particular, take steps for preserving and improving the breeds, and prohibiting the slaughter, of cows and other milch and draught cattle". Though this article does not use religious reference, the various Hindu nationalist groups urge for the religious symbolism of cow and call for a total ban on cow slaughter. Concerning this article in the constitution, several states of India legally prohibit cow slaughter to a limited or complete degree (Chegateri 2011).

There is no ban on cow slaughter in eight states of India, four of them have a Christian majority, such as Arunachal Pradesh, Meghalaya, Mizoram, and Nagaland. Although the rest of the four states named Arunachal Pradesh, Sikkim, Kerala, and Tripura have the Hindu majority population, the nationalist narratives are not politicized, and this has avoided the ban on cow slaughter. The politics in the latter four states is derived from the regional politics, rather than religious one. The two states where Hindus are in minority but have a ban on cow slaughter are Punjab with the Sikh majority, and Indian administered Kashmir with Muslim majority population. There is persecution against Sikhs and Muslims in those states by Hindu nationalists due to the nationalistic politics (Asrar 2017, Census 2011).

\subsection{History of cow protection}

The vegetarian ideologies in the sub-continent were inspired by the rise of Buddhism and Jainism, which urged many Hindus to stop eating the meat of cows as they produce milk. Until the first century A.D., killing a cow was considered as killing a Brahman, the highest caste in Hinduism (Winston 2015). However, the cow was not sacred to all the Hindus. Regarding the Hindus' beliefs, when the first Muslim Mughal emperor of the subcontinent banned cow slaughter in 1527, some Hindu kings did not support the emperor to enforce the ban in their states. "[A]ncient Hindus ate beef - the cow got its revered status around 500 A.D. Coinciding with an agricultural boom on the subcontinent, beef was not sacred during the Vedic period (1K-5K B.C.), which was the time when Hinduism's oldest scriptures - the Vedas were written", Dwijendra Narayan Jha notes in his book The Myth of the Holy Cow (Jha 2002). Even after the spread of vegetarianism, many Hindus continued eating beef. Since Brahmins received mass donations for cow protection, the Brahmins 


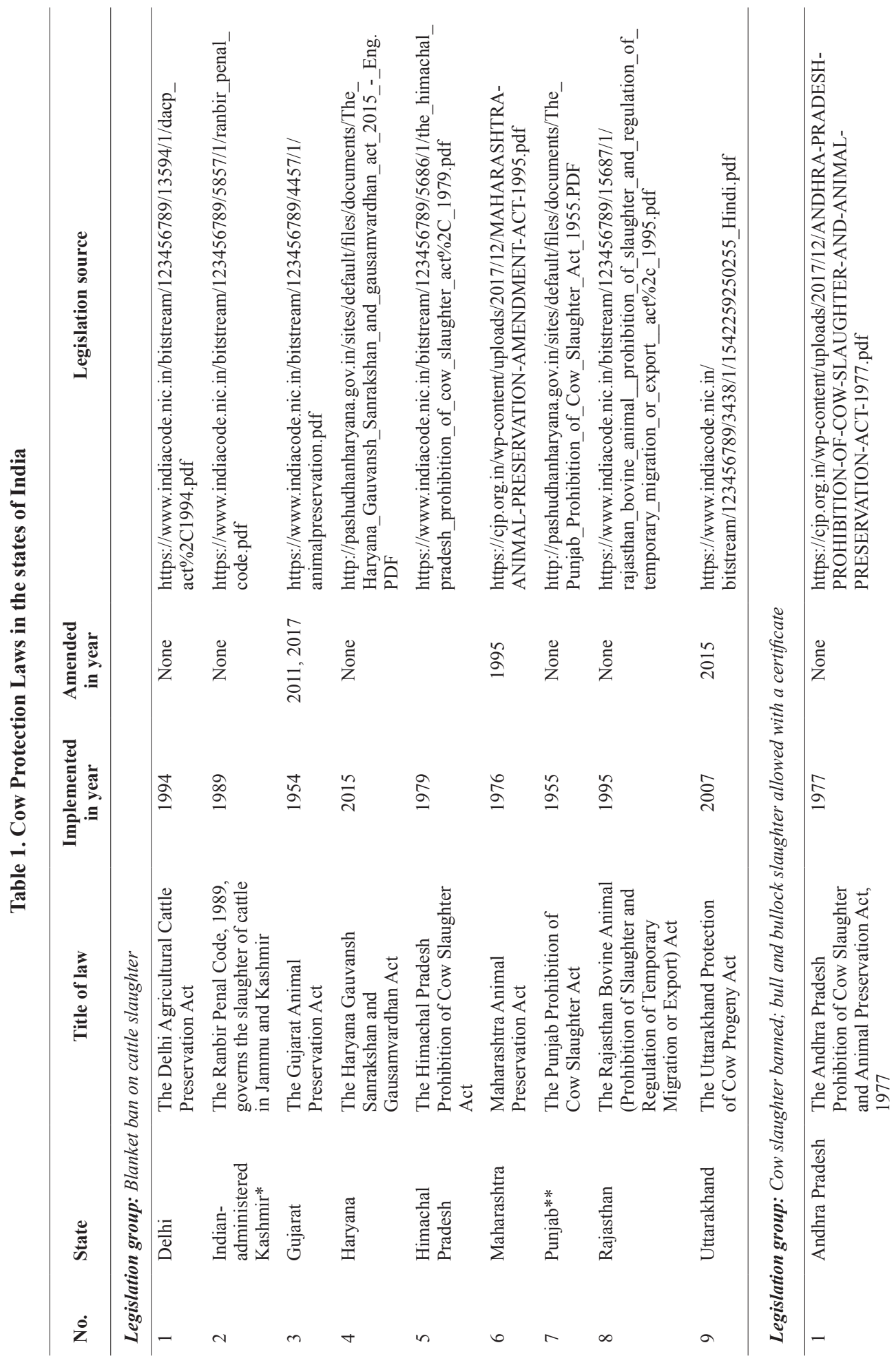




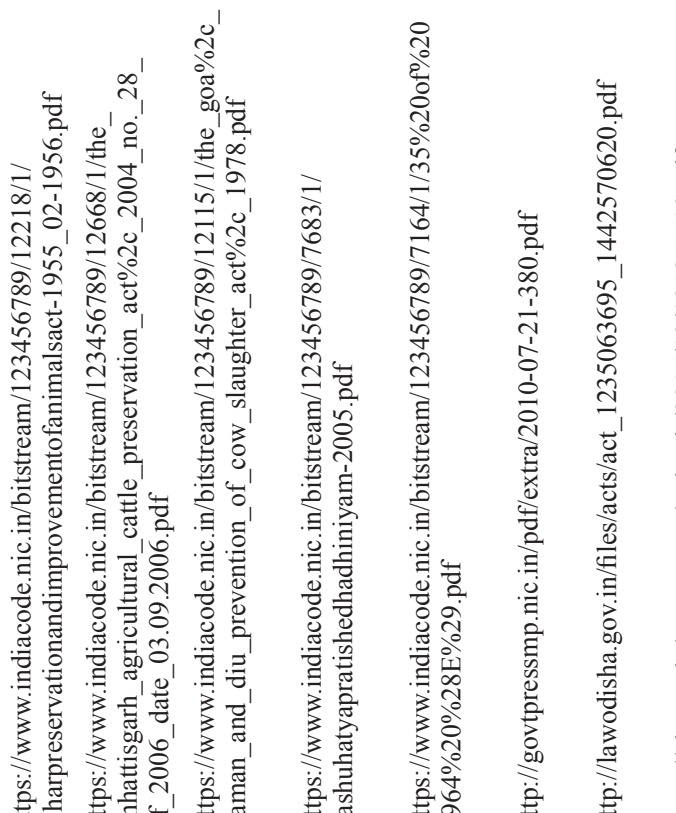

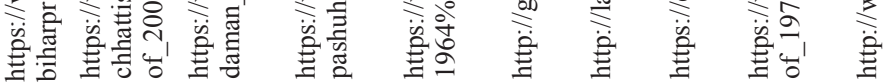

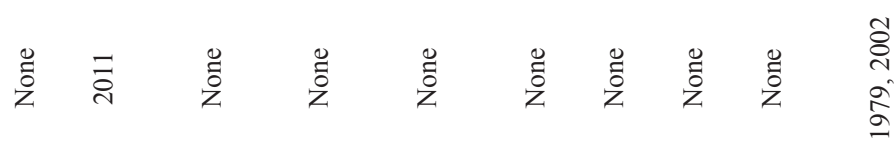

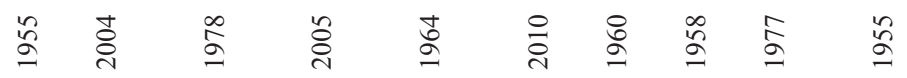

竞总

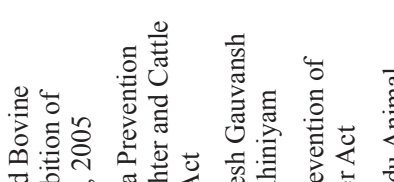

:

氶 总

㺃 离苛苞苞

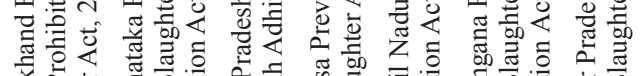

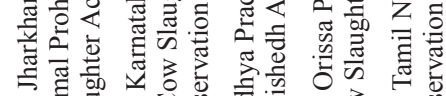

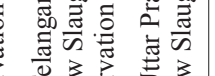

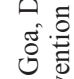
焉苟

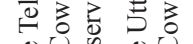
氙芯芯 总总进

\section{竞}

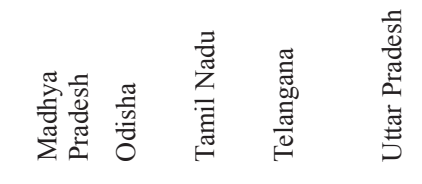

裏紊

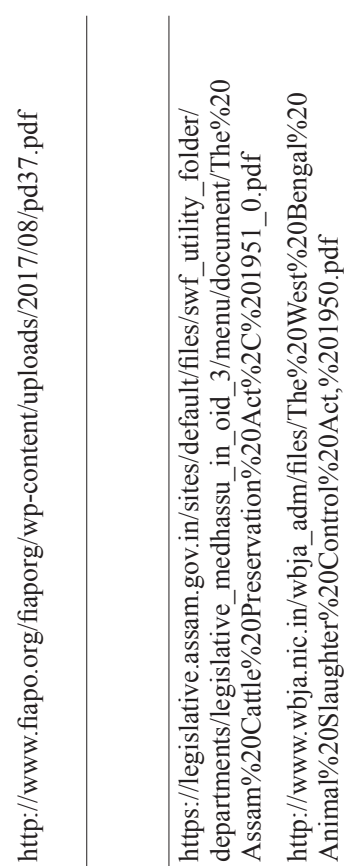

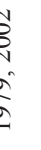


made cow protection controversial for various political arguments throughout history (Doniger 2017).

Cow-related violence was discovered in April 1881 when riots broke after a Muslim butcher was found traveling with an uncovered beef basket in Multan, a city now in Pakistan. Further, the Fyzabad and Ayudhya riots in 1912, Calcutta beef riots in 1909, widespread clashes between 1911 to 1917 in Patna, Muzaffarpur, Bihar, and Gaya cities, mob attack of 25000 Hindus on a Muslim village in Ibrahimpur on September 30, 1917, and Delhi riots in 1924 (Chatterjee 2016) are significant incidents of violence related to the cow protection in British colonial India. After the British left in 1947, India's government legalized cow protection, which later turned into the hands of Hindu nationalist vigilantes with radical political ideologies. "Those who are dying without eating beef can go to Pakistan or Arab countries or any other part of the world where it is available," BJP's Muslim union minister Mukhtar Abbas Naqvi said (Hindustan Times 2015).

In today's India, the cow has legal protection in 22 states from being slaughtered or harmed. With police's biased law enforcement, the victim families of cow vigilante violence are pushed into a vicious circle of investigations and threats of not pursuing their call for justice (Human Rights Watch 2019). The complex but systemic political narratives knit the web of religious-political discourse for cow protection. They use mob violence to create fear for Muslims to engage in the cow-industry. Such political scenarios are popular during the BJP's regime in India (Hindustan Times 2013). Cow protection at the intersection of religious and political narratives has been a critical factor of political divisiveness, mainly during the election seasons at local and national levels. For example, the current Prime Minister Narendra Modi extensively quoted his support of cow protection and future strategies to further strengthen this if he would be elected. Even the BJP's political leadership is not fully agreed upon the notion of cow protection. The BJP's General Secretary in Meghalaya state, David Kharsati, and Party Chief in Mizoram state, JV Hluna, did not support the ban on cow slaughter in their states but were only concerned with nutrition and hygiene measures while slaughtering (Parashar 2017).

\section{Methodology}

The exploratory research design was used to review secondary sources about cow vigilante violence in India. It reviews the historical, political, and social media usage subject to the cows' importance in India. The systematic review of the literature was performed using the Web of Science database from 1970 to 2020, three indexes used social sciences citation index, arts \& humanities citation index, and science citation index expanded. Scholars on cow protection in India conduct limited research; thus, Sunder (2018) and Kennedy et al. (2018) found from the database. This study expands the search to review books, index and non-index papers, blog posts, and news channel posts to find content. The review of content includes valid sources with author details, publication time, and established platforms such as news web 
portals. This study excluded personal notes and speeches of social activists and leaders to minimize the bias. Content review and analysis were performed to support the rationale for political discourse and social media for restorative justice.

\section{Social media and cow vigilante violence}

While the role of social media as a means of constructive and positive interactions is frequently highlighted by the researchers and social media companies, research done by the Observer Research Foundation (2018) highlighted that a growing section of social media followers in India use these platforms for provoking violence against Muslims. The study revealed that 'religio-cultural' food practices such as a ban on cow beef were the most common basis of hatred expressed on social media in India. The comments on social media mostly incited violence and bodily harm against minority Muslims (Siyech and Narain 2018). Most common subjects that induced online hate speech and violence ranged from opposition to the touchy issue of beef consumption and cow protection and interfaith marriages between Muslims and Hindus (Mirchandani 2018).

Social media platforms have been used extensively and strategically to spread hate towards religious minorities, particularly Muslims in India. The incidents of cow vigilante violence are mostly filmed or photographed and shared on social media for invoking the feeling of hate. Many recent lynching and cow vigilante violence cases resulted from WhatsApp and other social media messages blaming someone for cow slaughters (Gupta 2019). Cow vigilantes operate on social media platforms to locate their targets and publicize attacks. They intend to show the country's political leadership that making cow a national animal and hanging those who slaughter her has got extreme public support (Angad and Johri 2016, Ahuja et al. 2019).

In recent years, numerous cases have been witnessed where disinformation campaigns and doctored videos were shared on social media against Muslim youths claiming that Muslims harmed or slaughtered a cow, and then they were eventually killed by cow vigilantes (Youth Ki Awaaz 2019, Krishnan 2019, Krishnan 2016). Social media and close networks of personal relationships facilitated by social media have provided cow vigilantes a platform for achieving their 'holy goals' in India (Ward 2020). Cow vigilantes are now giving more importance to new technological tools and social media platforms to spread their message rather than the traditional ways, such as pamphlet distribution and slogan shouting. They use YouTube, Facebook, Twitter, TikTok, and WhatsApp to share videos, pictures, and texts of their activities related to cow protection (Bepari 2020). The use of social and mass media to disseminate recorded videos of violence over mobile networks is coupled with the central government's refusal to take timely action against perpetrators of cow vigilante violence. This evolved as a new mechanism to normalize the violence against Muslims and other minorities like Dalits (Siyech and Narain 2018). 


\subsection{Social media - expose, engage, act}

Cow vigilantes use social media for surveillance and monitoring purposes to perpetuate their violence against Muslims whose livelihood depends upon the cow-related industry (Parikh and Miller 2020). They least tend to communicate on WhatsApp to verify if the cow was being traded for business purposes or slaughter (Banaji et al. 2019). The cow Vigilantes chose WhatsApp to propagate violence in its end-to-end encryption, ensuring cow vigilante groups' privacy and not allowing the police and other law enforcement agencies to track vigilante plans (Narrain 2017). Many cow vigilantes manage multiple WhatsApp groups and social media accounts to disseminate information about the cow and its Muslim or Dalit carrier(s). They further direct the groups of vigilantes to reach a specific highway or location to catch the alleged smuggler(s) of cows and engage in violence. Social media groups are considered vital for cow protection (Mukherjee 2020). The free and cross-platform video sharing services like Facebook messenger, TikTok, and WhatsApp have enhanced the practices of sharing content on mob violence as disinformation. Social media has complex impacts on cow vigilante violence in India by spreading fake news and outreach of mob lynching incidents (Banaji et al. 2019).

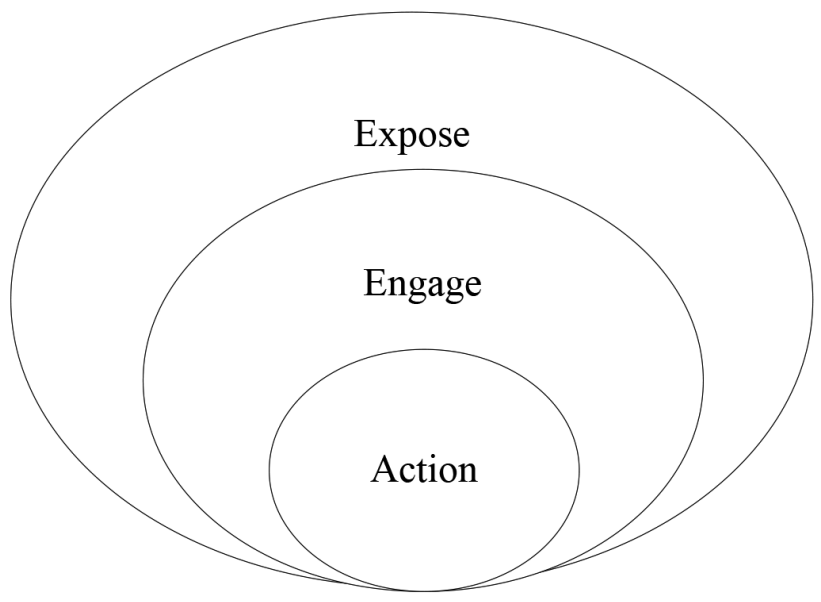

Figure 1. Action, engage, expose (Liou 2013).

This paper proposes restorative utilization of social media platforms to address the nonviolent communication for cow vigilante violence in India. The nonviolence activists could use social media to capture the victimization to expose physical, economic, and psychological damage caused by the vigilantes. It could break nonviolence discussion on social media platforms by presenting the other side of the story and countering disinformation around cow protection. Social media users could engage in comments and discussions to allow critical thinking while believing 
in cow protection's violent narratives. This engagement of like-minded nonviolence activists and general public could produce a debate on preventive approaches through monitoring and denouncing violence. It could engage the Hindu activists to promote the cows' nonviolent symbolism through different social media platforms, which can decrease the frequency of cow vigilante violence incidents.

\section{Restorative justice theories to practice amidst cow vigilantism}

The situation analysis of cow vigilante violence guides that historic damage caused by the Muslim rulers of subcontinent India are key reasons why the Hindu nationalists carry out violence against Muslims. The rapid increase in India's Muslim population and their cow-industry monopoly reminds Hindu nationalists of those damages. In such a scenario, the politically nationalist ideologies further spark the aggression and intent to take revenge from Muslims. This paper has identified various theories of restorative justice that could guide the transformation of cow vigilante violence situation factors into peaceful coexistence of Hindus and Muslims in India.

\subsection{Post-conflict justice model}

In response to an offense, the restorative justice urges to repair the individual relations and social harm through volunteer engagement of victims and offenders. It requires a transparent and just response to the violent incident by adopting restorative approaches to justice rather than punitive ones. This paper identifies that the TARR (Truth, Accountability, Reconciliation, Reparation) Model by Weitekamp et al. (2006) could help address the harm caused by cow vigilante violence in India.

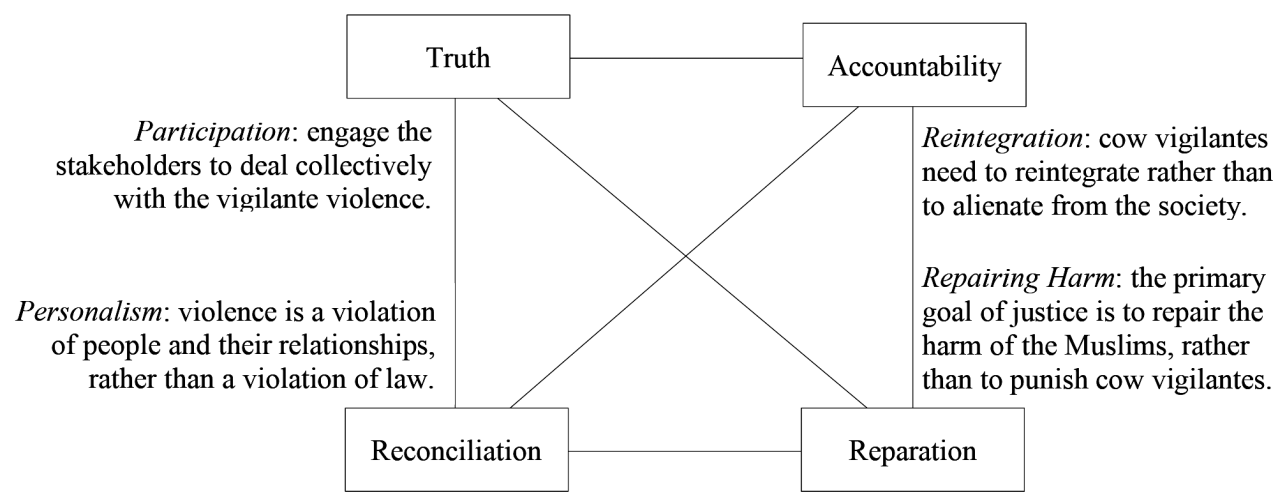

Figure 2. Post Conflict Justice Model (Weitekamn et al. 2006). 
Truth is the prime principle of restorative justice, which helps to understand the root causes of a phenomenon like mob violence against Muslims by the cow vigilantes in India. The TARR model depicts that truth can be sought through diverselevel stakeholders' participation in the situation, which enables to disseminate their information and knowledge. This paper views that cow vigilante violence in India causes multi-layered victimization, both indirectly and directly. Apart from the direct violence on Muslim suspects for cow slaughter, the mob lynching leaves severe socioeconomic and psychological damage to their families, friends, and even the incident witnesses. Hence, direct and indirect stakeholders' participation in seeking the truth is necessary for informed responses to violent incidents around the notion of cow protection.

The restorative justice principles would require the cow vigilantes to be accountable in a supportive way leading towards their reintegration for an inclusive society. Since the punitive response to a crime prevents the offender from smooth reintegration into society, the restorative response could sensitize the offender about the damage of violent actions. The collaborative engagement of cow vigilantes in the accountability of violent incidents against Muslims could help the vigilantes understand the harm their actions cause. It will help to change their understanding and behavior for problem-solving and reintegration, rather than alienation from society.

Since the cow vigilante violence incidents also affect the friends and families and direct victims, restorative justice would aim to repair their damage and trauma. This reparation could range from monetary support to the families of direct victims and their families, psycho-social support, and reassurance of safety in their business activities related to the cow market in India. Following personalism, restorative justice would require repairing Hindu nationalists' relationships and Muslims engaged in cow-related businesses. It will urge the emotional involvement of Hindu nationalists and Muslims to restore their broker relationships.

\subsection{Galtung's peace model}

The situation analysis of cow vigilante violence in India, amidst the Hindu nationalist political party's rule, suggests that the vigilantism could be dealt with a three-level response as outlined by Galtung (1976) in the book entitled Impact of Science on Society. The selection of response level depends upon the severity of the situation. This paper identifies the restorative utilization of Galtung's three approaches to establish, maintain, and promote peace in cow vigilante violence contexts of India. 


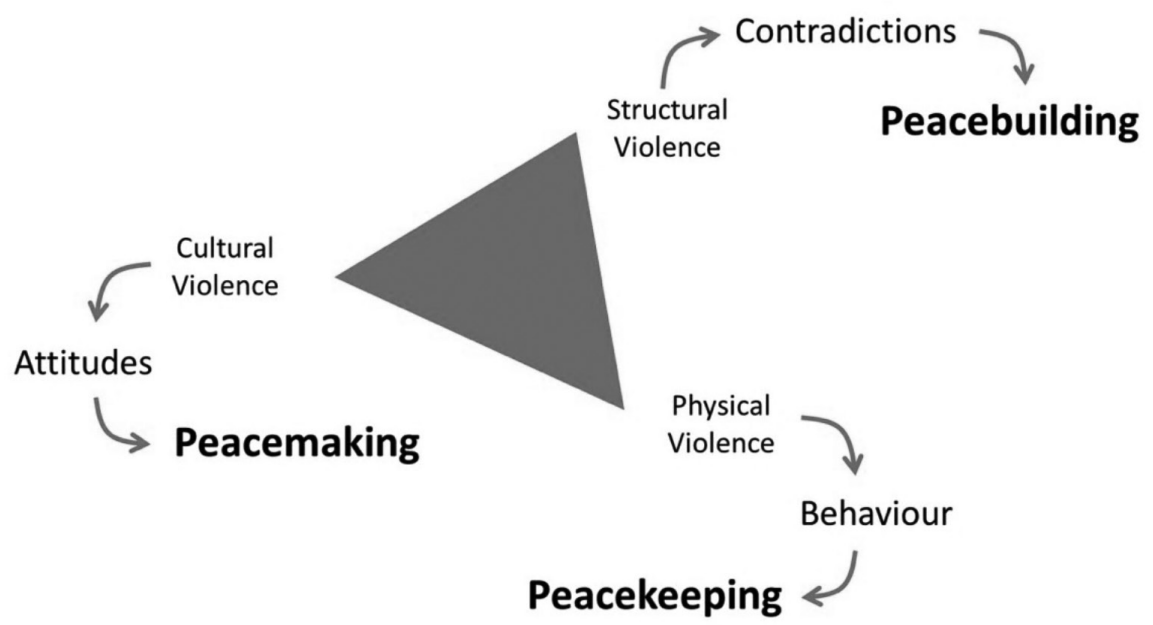

Figure 3. Three approaches to peace (Galtung 1976).

The incidents of direct violence such as mob lynching could fall into the first degree of situation severity requiring immediate response by law enforcement. Since the delayed response by the first responder police officers and arrests of victims encourages cow vigilantes' violence, the capacity of first responder police officers could be built on inclusive and just law enforcement. Their peacekeeping efforts could focus on the immediate response to vigilante violence incidents to prevent the severity of physical and psychological harm to the victims and identify restorative practices for the offenders' behavioral reformation. The immediate response could help tertiary, secondary, and primary prevention of vigilante violence incidents amidst political discourse about the violent protection of cows (Bazemore 1998: 28).

This paper proposes to draw an ethical and humane charter of nonviolence to discourage cow vigilante violence for peacemaking purposes. Since the punitive response to the violence does not help prevent violent behaviors, transformative and adaptive principles could sensitize the vigilante Hindu nationalists in India. The nonviolence charter could help identify the offenders and victims without religious prejudice as Hindus hold a majority in law enforcement, and in the country's population. The nonviolence charter articles could be publicly endorsed by the locally respected individuals, including religious leaders of Hindus and Muslims. Since Hindu political leaders have a significant role in promoting vigilante violence in cow protection, their endorsement would make a difference in denouncing the violence narratives among the Hindu nationalists. The Hindu activists could restore the nonviolence symbolism of the cow by condemning the violent approaches of its protection.

Since nonviolence requires transformative behaviors, Galtung (1976) views peacebuilding as a crucial stage for systemic change of a conflict or violent situation. The cow vigilante violence is deeply rooted in Hindu nationalism's political 
narratives, which requires a transformative shift of political spheres misusing the Hindu sacredness of cows for political interests. The masses could be sensitized to the nonviolence symbolism of cows in Hinduism and the nonviolent teachings of Gandhi, the founding father of India. The advocacy groups could bridge the divide among Hindus and Muslims through interfaith and restorative activities at the grassroots level.

\subsection{Scenario transformation practices}

The cow vigilante violence incidents in India are not merely incidents but a scenario built by the political narratives of Hindu nationalism. The restorative justice principles urge for change rather than respond to the situation around incidents. Kahane (2012) aims for the stakeholder engagement to transform the scenario with potential harm or trauma. This paper has applied Kahane's scenario transformation practices to cow vigilantism in India to help understand the conflict contexts and bridge the change.

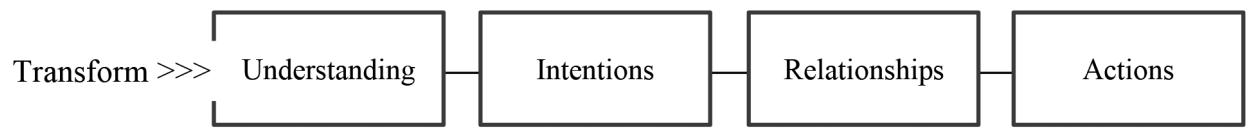

First, the law enforcement agencies of India must change their understanding, without political biases, of the situation around the notion of cow protection and the associated violence. This could help the first-responder police officers to understand the scenarios around violent incidents and proceed with restorative response rather than punitive and biasness. It could guide them in identifying the offenders and victims, proceed with fair investigations, and acknowledge the violence against Muslims caused by the Hindu nationalists. It will be challenging to adopt amidst the Hindu majority country governed by the Hindu nationalist political party.

Second, political actors need to transform their narratives for peaceful coexistence rather than divisive statements and violence provoking remarks. Democratic values of India, Gandhi's teaching for forgiveness, and nonviolence symbolism of the cow itself must guide the narratives being practiced in the political spheres. Further, the peaceful efforts coordinated with Muslim leadership could help shape the country's political nonviolence scenario amidst dominant Hindu political and nationalist ideologies. Muslim leadership's public acknowledgment of the historic harm caused by the Muslim rulers could discourage violent and revenge narratives of the Hindu nationalists.

Third and most important, perceptions towards each other must be transformed to turn the violent behaviors into peaceful coexistence. The human rights and justice activists could design and implement programs on minority inclusion and narrative shifts by denouncing the politically driven violent and nationalist narratives. It could lead to the fourth stage of scenario transformation by accelerating the relations between Hindus and Muslims for an inclusive and tolerant India. 


\subsection{Restorative governmentalities}

The Muslims of India view cow protection as political rather than religious, and urge for the reformed governance system to address the issues of cow vigilante violence. Since cows are subject to governance, but not all the states of India uniformly govern them. It relies significantly upon the political and nationalist narratives where politicians seek personal interests over the Hindus' respect for cows. This paper has identified the need for restorative governmentalities (Palvich 2005) to handle the situation amidst the Hindu nationalist political narratives in the country.

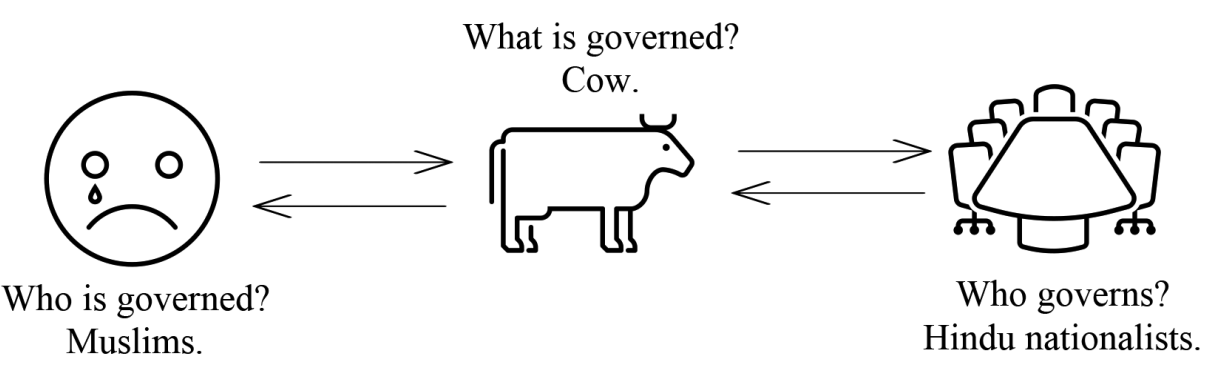

Figure 4. Restorative governmentalities (Akram et al. 2021).

This paper proposes the engagement of community groups to govern the issue of cow vigilante violence in India. Interfaith committees at grassroot level could be established to monitor, report, and mediate the cow vigilantism with a restorative approach and authority. The Hindu members of such committees could help monitor WhatsApp and other platforms that are being utilized to organize lynching of Muslims engaged in cow-related businesses. The political denouncement of cow vigilante violence incidents could empower the interfaith committees to mediate Hindu nationalists and Muslims in cow-related businesses effectively. Further, political denouncement of cow vigilantism will restore the confidence of Muslims in Indian democracy, which could lead to peaceful and trusted coexistence. The engagement of Muslims to govern protection for cows in respect to Hindu's religious beliefs could help to repair the interfaith relationships.

\section{Restorative models to respond to cow vigilante violence}

The restorative justice principles view conflicts as transformable with acknowledging the damage to victims by potential offenders. In the context of India, the intensity and frequency of cow vigilante violence can be reduced if Muslim representatives acknowledge the historic harm caused by Muslim rulers of the subcontinent, and Hindu nationalists accept that acknowledgment. Since 
cow vigilante violence is complex, it needs a holistic and systemic shift towards nonviolence and inclusion. This paper has modified the four models of restorative justice practice to address the violent situation of India, where the sacredness of the cow has been politicized with manipulated violent narratives (Wilson 2001).

\subsection{Victim-offender mediation}

Since the mob violence by cow vigilantes is often urged by misinformation, the offenders must at least get the chance to know whether the victim was engaged in the killing of cows. It also prevents the vigilantes from learning more about the personal and situational circumstances of Muslim victims of vigilante violence. This paper views the victim-offender mediation as an opportunity to exchange the learning about the facts of cow-related businesses by Muslims and the emotional association of Hindus with cow protection. The victim-offender mediation process will bring the Hindu nationalists and Muslims to share their grievances without any fear as they will be meeting in a safe place and a neutral person or group is mediating the situation. The victim Muslims will get an opportunity to share physical, emotional, and psychological impacts caused by the cow vigilantes. Further, the Hindu nationalists could get an in-person chance to share their grievances and concerns on businesses related to the cows. The series of sessions between Hindus and Muslims could lead to the restoration of losses by healing victims and developing relationships.

\subsection{Community reparative boards}

This paper proposes to utilize the concept of community reparative boards to respond to cow vigilante violence in India. To transform the systemic violence, community boards could help restorative healing by recognizing the harm acknowledged by stakeholders in the community (Woolford 2009). The community reparative boards could be a space where offenders can acknowledge the harm they have caused over history - in the case of Muslims and today's India - in the case of Hindus. The possible but informal community reparative boards could be interfaith coalitions, human rights defender networks, associations of transporters, corporations of business related to meat, and youth councils. It may sensitize the offenders, Hindu nationalists, to feel accountable for the violence they cause against Muslims in businesses related to the cows. It could promote citizens' ownership of the cow vigilante violence issue in India, which will ensure the strengthened engagement of stakeholders aiming for the minority inclusive India.

From the platforms of community reparative boards, Muslim leaders could acknowledge the historic harm caused by Muslim rulers to the Hindus in subcontinent India. It invites Hindu nationalists to rethink their aggressive and revengeful behaviors towards the Muslims, resulting in enhanced interactions and understanding. Such an acknowledgment could help Muslims and Hindus to move forward with restored relationships in the best interest of their communities and the country. 


\subsection{Family group conferencing}

The concept of family group conferencing could also help address the harm caused by the cow vigilantes by engaging the victims and offenders and their support systems like the politicians in the case of Hindu nationalists. With the offender's prioritized opportunity to describe the incident of violence, the conference facilitators could engage other participants from the sides of victims and offenders to list the psychosocial impacts of the incident. Those narrations could help the offender understand the intensity of harm they have caused for victims and their associated network of families and friends. It could also guide the offender with required changes in their aggressive and violent behaviors for the alternative peaceful ways to convey their message amidst cow protection. The modified family group conferencing in cow vigilante violence in India could bring the victims and offenders in direct communication that will increase the offenders' awareness about the human impacts of their violent behavior. It will also acknowledge the collective responsibility of the violent incidents to offenders and their support systems like politicians urging for a wholistic change in the violent narratives.

\subsection{Circles for healing and support}

Circles is an indigenous practice to heal the damage by offering a constructive and informed response to physical and psychological damage incidents. The circles could create an inclusive and dignified space for the Muslims and Hindus to rebuild their strained relationships aiming for an inclusive and just society. Since the circles offer equal participation opportunities to those involved, it will help determine the root causes for the violence against Muslims accused of killing the cows. The nonpartisan advocacy organizations and local community activists must respond to cow vigilante violence through restorative justice models stated above. Since the transformative process is complex and stretched over the years, the restorative justice efforts must be consistent and nonpolitical. The potential donors of mediating or facilitating individuals or organizations must not have the political influence to divert any justice processes.

\section{Conclusion}

This paper discussed political discourse and people's expression of dark emotions on social media about cow vigilante violence in India. Violence against Muslim minorities is largely derived from political drivers grounded in historical damage by Muslim rulers as claimed by Hindu nationalists. An increase in violence over the notion of cow protection evolved from Hindu nationalism. By denying the nonviolent symbolism and ignoring Gandhi's nonviolence principles, this argument urges political patronage of violent discourse for cow protection. Throughout history, political issues have contributed to multiple legislation on cow slaughter in Indian states. Vigilante groups, also known as social activists in India, get the support of 
social media platforms to disseminate content on cow vigilante and publicize for political benefits.

In order to overcome the turbulent situation, theories of restorative justice would be a great help to transform cow vigilante violence into a peaceful coexistence of Hindus and Muslims in India. Galtung's peace model guided the functionality of peacebuilding, peacemaking, and peacekeeping among Hindus, Muslims, and Dalit minorities in India. The results indicate a change in the perception of stakeholders around cow safety. To ensure the safety of cows currently being unlawfully slaughtered, Muslims should set an example of extended cooperation with Hindus and acknowledge the historical damage their ancestors caused to the Hindus. In addition, steps should be taken by the Indian government to discourage nationalist ideologies that urge mob violence against Muslims. Collaborative dialogue between Muslims and Hindus will help both sides observe and understand each other's concerns and complaints about the history of Muslim rule over the subcontinent. It will further support overcoming the cow vigilante violence in several states of India.

Addresses:

Muhammad Akram

Center for Justice and Peacebuilding

Eastern Mennonite University

1200 Park Road, Harrisonburg

Virginia 22802

United States

E-mails: muhammad.akram@emu.edu and akramuhammad1@gmail.com

Asim Nasar

Azman Hashim International Business School

Universiti Teknologi Malaysia

81310 Johor Bahru

Johor

Malaysia

E-mail: aasimnasar@gmail.com

Muhammad Rizwan Safdar

Institute of Social and Cultural Studies

University of the Punjab

Quid-e-Azam Campus, Canal Bank Road,

Lahore 54590

Pakistan

E-mail: drrizwansafdar.iscs@pu.edu.pk 


\section{References}

Adcock, C. (2018) "Cow protection and minority rights in India: reassessing religious freedom". Asian Affairs 49, 2, 340-354.

Ahuja, J., T. Bjørgo, and M. Mareš (2019) "Protecting holy cows: Hindu vigilantism against Muslims in India”. In T. Bjørgo and M. Mareš, eds. Vigilantism against migrants and minorities, 55-68. Abington and New York: Routledge.

Angad, A., and A. D. Johri (2016) "The cow keepers: some cattle vigilante groups operating in Delhi and neighboring states". The Indian Express, August 8. Available online at $<\mathrm{https}$ ://indianexpress. com/article/india/india-news-india/the-cow-keepers-the-cattle-vigilante-groups-operating-indelhi-and-neighbouring-states/>. Accessed on 07.04.2021.

Akram, M., A. Nasar, M. R. Safdar, and F. Sher (2021) "Restorative justice approach to cow vigilante violence in India". Journal of Ethnic and Cultural Studies 8, 1, 190-205.

Asrar, S. (2017) "India suspends ban on trade of cattle for slaughter". Al-Jazeera, July 11. Available online at <www.aljazeera.com/indepth/features/2017/07/india-suspends-ban-trade-cattleslaughter-170711075047079.html/>. Accessed on 07.04.2021.

Banaji, S., and R. Bhat, A. Agarwal, N. Passanha, and M. Sadhana Pravin (2019) "WhatsApp vigilantes: an exploration of citizen reception and circulation of WhatsApp misinformation linked to mob violence in India". LSE. Available online at <https://blogs.lse.ac.uk/medialse/2019/11/11/ whatsapp-vigilantes-an-exploration-of-citizen-reception-and-circulation-of-whatsappmisinformation-linked-to-mob-violence-in-india/> . Accessed on 07.04.2021.

Bazemore, G. (1998) "Guide for implementing the balanced and restorative justice model". U.S. Department of Justice, Office of Justice Programs, Office of Juvenile Justice and Delinquency Prevention.

Bepari, S. (2020) "Cow-politics in India: a study on recent developments". National Journal of Multidisciplinary Research and Development 5, 2, 32-38.

Business Line (2019) "Livestock population in India rises 4.6 percent to nearly 546 million, shows census". The Hindu Business Line, October 16. Available online at $<$ www.thehindubusinessline. com/economy/agri-business/livestock-population-in-india-rises-46-to-nearly-536-m-showscensus/article29708130.ece\#>. Accessed on 28.10.2019.

Chatterjee, A. K. (2016) "How the British gave a fillip to cow vigilantism in colonial India". Huffington Post. Available online at <www.huffingtonpost.in/arup-k-chatterjee/how-the-british-gave-afillip-to-cow-vigilantism-in-colonial-ind_a_21447730/>. Accessed on 30.10.2019.

Census 2011 "Religious census 2011". Available online at $<$ https://www.census2011.co.in/religion. php>. Accessed on 28.10.2019.

Chigateri S. (2011) 'Negotiating the 'sacred' cow: cow slaughter and the regulation of difference in India”. In M. Mookherjee, ed. Democracy, religious pluralism and the liberal dilemma of accommodation. (Studies in Global Justice, 7.) Springer, Dordrecht. DOI: https://doi. org/10.1007/978-90-481-9017-1_8

Doniger, W. (2017) "Hinduism and its complicated history with cows (and people who eat them)". The Conversation. Available online at $<\mathrm{http}$ ://theconversation.com/hinduism-and-its-complicatedhistory-with-cows-and-people-who-eat-them-80586>. Accessed on 30.10.2019.

Galtung, J. (1976) Three approaches to peace: peacekeeping, peacemaking and peacebuilding. Copenhagen: Christian Ejlers. 
Gowen, A. (2018) "Why India has 5 million stray cows roaming the country". The Washington Post, July 16. Available online at <www.washingtonpost.com/world/ 2018/07/16/amp-stories/whyindia-has-million-stray-cows-roaming-country/>. Accessed on 28.10.2019.

Gundimeda, S. and V. S. Ashwin (2018) "Cow protection in India: from secularising to legitimating debates". South Asia Research 38, 2, 156-176.

Gupta, I. (2019) "MOB violence and vigilantism in India". World Affairs: The Journal of International Issues 23, 4, 152-172.

Hindustan Times (2013) "107 killed in riots this year; 66 Muslims, 41 Hindus". Hindustan Times, September 24. Available online at <www.hindustantimes.com/delhi/107-killed-in-riotsthis-year-66-muslims-41-hindus/story-uqHMNT093ZqMa0WAsWdIpJ.html>. Accessed on 20.01.2020.

Hindustan Times (2015) Those who want to eat beef should go to Pak: Mukhtar Abbas Naqvi”. Hindustan Times, May 22. Available online at $<$ https://www.hindustantimes.com/india/those-who-wantto-eat-beef-should-go-to-pak-mukhtar-abbas-naqvi/story-kTyciMp58MrUhrWJfp5kFK.html>. Accessed on 10.10.2019.

Human Rights Watch (2019) "Violent cow protection in India, vigilante groups attack minorities". Human Rights Watch. Available online at <https://www.hrw.org/report/2019/02/18/violentcow-protection-india/vigilante-groups-attack-minorities $>$. Accessed on 10.01.2020.

Jha, D. N. (2002) "The myth of the holy cow". London and New York: Verso.

Kahane, A. (2012) "Transformative scenario planning: changing the future by exploring alternatives". Strategy \& Leadership 40, 5, 19-23.

Kennedy, U., A. Sharma, and C. J. C. Phillips (2018) "The sheltering of unwanted cattle, experiences in India and implications for cattle industries elsewhere". Animals 8, 5, 1-8. DOI: https://doi. org/10.3390/ani8050064

Krishnan, M. (2016) “Cow vigilantism spreads fear and rage through India”. Deutsche Welle, August 9. https://p.dw.com/p/1JeZy

Krishnan, M. (2019) “Indian religious minorities face increased violence under Modi”. Deutsche Welle, June 25. Available online at $<$ https://p.dw.com/p/3L3Fa $>$. Accessed on 07.04.2021.

Liou, C. (2013) Using social media for the prevention of violence against women. (Working Paper, 6.) Bangkok: Partners for Prevention. Available online at $<\mathrm{http} / /$ partners4prevention.org/sites/ default/files/resources/socialmedia_final.pdf $>$. Accessed on 07.04.2021.

Mirchandani, M. (2018) "Digital hatred, real violence: majoritarian radicalisation and social media in India”. ORF Occasional Paper 167, 1-30.

Narayanan, Y. (2019) "Cow is a mother, mothers can do anything for their children! Gaushalas as landscapes of anthropatriarchy and Hindu patriarchy". HYPATIA. A Journal of Feminist Philosophy 34, 2, 195-221. DOI: https://doi.org/10.1111/hypa.12460

Narrain, S. (2017) "Dangerous speech in real time: social media, policing, and communal violence". Economic and Political Weekly Engage, 24.

Parashar, U. (2017) "No beef ban if we come to power in poll-bound northeast states: BJP”. The Hindustan Times, 28 March. Available online at <www.hindustantimes.com/india-news/no-beef-ban-ifwe-come-to-power-in-poll-bound-ne-states-bjp/story-s73qgNWp0gWNf3B6NAJIbM.html>. Accessed on 08.01.2020.

Parikh, A. and C. Miller (2020) "When sacred cows become tools of the state". Available online at $<$ https://edgeeffects.net/beef-testing-beef-ban/>. Accessed on 04.02.2021. 
Pavlich, G. (2005) Healing crime's harm. In his Governing paradoxes of restorative justice, 25-42. London: GlassHouse Press.

Siyech, M. and A. Narain (2018) "Beef-related violence in India: an expression of Islamophobia". Islamophobia Studies Journal 4, 2, 181-194. DOI:10.13169/islastudj.4.2.0181

Sunder, J. (2018) "Religious beef: Dalit literature, bare life, and cow protection in India". Interventions 21, 3, 337-353. DOI: https://doi.org/10.1080/1369801X.2018.1558097

Upadhyay, A. (2016). "Cow urine can sell for more than milk in India". Bloomberg. Available online at $<$ www.bloomberg.com/news/articles/2016-07-17/cow-urine-can-sell-for-more-than-milk-inindia $>$. Accessed on 04.02.2021.

Ward, M. (2020) "Walls and cows: social media, vigilante vantage, and political discourse". Social Media + Society 6, 2. DOI: https://doi.org/10.1177/2056305120928513

Weitekamp, E. G., S. Parmentier, K. Vanspauwen, M. Valinas, and R. Gerits (2006) "How to deal with mass victimization and gross human rights violations: a restorative justice approach". NATO Security Through Science. Series E: Human and Societal Dynamics 13, 217.

Wilson, J. J. (2001) "A comparison of four restorative conferencing models". Juvenile Justice Bulletin. Available online at $<$ https://www.ojp.gov/pdffiles1/ojjdp/184738.pdf>. Accessed on 07.04.2021.

Winston, K. (2015) "The 'Splainer: What makes the cow sacred to Hindus?" The Washington Post, November 5. Available online at $<$ www.washingtonpost.com/national/religion/ the-splainerwhat-makes-the-cow-sacred-to-hindus/2015/11/05/acdde3e2-840c-11e5-8bd2-680fff868306 story.html >. Accessed on 28.10.2019.

Woolford, A. (2009) "Delineating the restorative justice ethos: history, theory, and restorative justice". In The politics of restorative justice: a critical introduction. Black Point, NS: Fernwood Publishing.

Youth Ki Awaaz (2019) "When it's not about cows, it's about 'Jai Shri Ram"'. Human Rights, News, Politics, June 29, Available online at $<$ https://www.youthkiawaaz.com/2019/06/lynched-inindia/>. Accessed on 28.10.2019. 